\title{
Recovery of Silver and Gold From Electronic Waste by Electrodeposition in Ethaline Ionic Liquid
}

\author{
ANA MARIA POPESCU ${ }^{1}$, VASILE SOARE ${ }^{2}$, OLGA DEMIDENKO ${ }^{3}$, JOSE M. CALDERON MORENO ${ }^{1}$, \\ ELENA IONELA NEACŞU ${ }^{1}$, CRISTINA DONATH ${ }^{1 *}$, MARIAN BURADA ${ }^{2}$, IONUT CONSTANTIN ${ }^{2}$, \\ VIRGIL CONSTANTIN ${ }^{1 *}$ \\ ${ }^{1}$ Romanian Academy, "Ilie Murgulescu" Institute of Physical Chemistry, 202 Splaiul Independentei \\ 060021, 060021, Bucharest, Romania \\ ${ }^{2}$ Institute of Non-ferous and Rare Metals-IMNR,102 Biruintei Blvd., 077145, Pantelimon, Ilfov County, Romania \\ ${ }^{3}$ Scientific-Practical Materials Research Centre, National Academy of Belarus, P. Brovki 19 Str., Minsk, 220072, \\ Belarus
}

The recycling of metals from electronic equipment waste (e-waste) is of great concern today. The work described in the article focuses on the application of ionic liquids (ILs) to selectively recover of precious metals ( $\mathrm{Ag}$ and $\mathrm{Au}$ ) from the anodic slime obtained at the anodic dissolution of cast $e$ waste. The ingots obtained from molten and cast anodic slime were selectively dissolved in ILs. Silver and gold compositions of the ingots: $39.7 \mathrm{wt} . \%$ and respectively $18.9 \mathrm{wt} . \%$. The IL used was an eutectic mixture of choline chloride with ethylene glycol in a 1:2 molar ratio. As catalyticloxidizing agent, there was used pure iodine in a concentration of 0.1-0.2 mol $\cdot \mathrm{dm}^{-3}$ at 298$303 \mathrm{~K}$. Cyclic voltammetry was employed for the determination of the electrochemical windows of ILs as well as of the dissolution and electrodeposition potentials of principal metals present in the ingot (anode). For $\mathrm{Ag}$ and $\mathrm{Au}$, the deposition potentials determined were $0.074 \mathrm{~V}$ and respectively $0.696 \mathrm{~V}$. The XRD and SEM-EDX analyses revealed that the content of precious metals in the cathodic deposits was $99 \mathrm{wt} . \%$ for Ag and respectively $>70 \mathrm{wt} \% \%$ for Au. We demonstrated that ILs electrolytes could be a solution to selective recovery of precious metals from e-waste.

Keywords: Anodic dissolution; Au; Ag; ionic liquids; e-waste

The need to develop new waste recycling methods, especially when dealing with waste of heterogeneous composition, has become ever more important, since the newly implemented and impending legislations encouraged it by setting high recovery and recycling targets. Waste management is a key feature in modern societies, as it involves financial, environmental and social issues. More specific directives are targeted at controlling a specific type of waste, such as the e-waste.

The waste from electrical and electronic equipment represents around some millions tonnes of domestic e-waste a year. Moreover, it is growing more rapidly than any other types of waste, but it also represents a challenge due to the multiplicity of its sources and its heterogeneous nature, which render recycling extremely difficult. A way to tackle the diversity of e-waste is to separate the bulk waste into different fractions of similar composition, which can be specifically treated. The processing of e-wastes resulting from the industry represents a major technological challenge and at the same time a major opportunity, taking in consideration two aspects: (a) the protection of the environment through the treatment of the toxic elements contained in e-wastes; (b) the recovery of the useful metals present in the e-wastes and the provision of alternative sources of valuable metals for the industry [1-3]. Printed circuit boards (PCBs), as main e-waste component, have a contents of $40 \mathrm{wt} . \%$ metals, $30 \mathrm{wt} . \%$ organic compounds, $30 \mathrm{wt} . \%$ ceramics. Therefore, they may be a very important source of nonferrous $(\mathrm{Cu}, \mathrm{Al}, \mathrm{Fe}, \mathrm{Ni}, \mathrm{Pb})$, rare and precious $(\mathrm{Au}$, $\mathrm{Ag}$, In, Sr, Ta, etc.) metals. The conventional methods for processing e-wastes are pyrometallurgical, hydrometallurgical or combined methods, all applied after a prior treatment through physical-mechanical methods. The hydrometallurgical treatments are generally more flexible in terms of the process progress. Hydrometallurgical treatment involves the use of a wet stage where solvent dissolves metals in their cationic form. Metals are then recovered under their solid form by precipitation (chemical or electrochemical). The processes can be selective or can dissolve all metals present in the waste. However the processing by hydrometallurgy or pyrometallurgy typically has a high energy demand, and associated release of carbon dioxide. Thus there is a need to develop more energy-efficient and environmentally-compatible methods. The use of electrochemical methods for processing waste printed circuit boards (WPCBs) presents the advantages of reducing the reagent consumption and of increasing the recovery efficiency for valuable metals and it has a mitigated impact on the environment [4-6]. To solve the problem of e-waste collection and treatment, new waste treatment processes need to be developed to improve the global efficiency,

email: cristidonath@yahoo.com; virgilconstantin@yahoo.com 
selectivity, cost and environmental impact of recovery and to comply with the ambitious objectives of the EU legislations $[7,8]$. Recently, studies have been carried out to investigate anodic dissolution, a new and very promising method for the recovery of metals from WPCBs. This method consists of the direct extraction of metals through an electrochemical process without a prior chemical dissolution. In general, the anodic dissolution of the metal will begin when the anodic potential will be more positive than the reversible electrode potential of the respective metal.

Here, we show that ILs are one more energy-efficient and environmentally-compatible method and that they can be used to selectively dissolve and recover precious metals. They are powerful solvents and electrolytes with potential for high selectivity in both dissolution and recovery of metals. Deep eutectic solvents (DES) are a form of ILs that are mixtures of quaternary ammonium salts such as choline chloride, $(\mathrm{ChCl})$ with hydrogen-bond donors such as ethylene glycol (EG). DESs are environmentally benign, chemically stable and, furthermore, the components are already produced in large quantities at low cost. This DES formed by ChCl-EG, named Ethaline, has a unique combination of properties that include the high solubility of a big range of neutral and charged metallic species. It has been discovered that iodine has a significantly greater solubility in a DES environment than in water, and displays reversible redox behaviour whilst maintaining a high positive redox potential [9]. These properties allow the use of iodine as a benign, and efficient electrocatalytic agent. New research proves that ILs can provide new environmentally-friendly approaches to processing a variety of ores, in particular those that are difficult and energy-intensive to treat [10]. Whilst there is now a large literature and extensive application of these liquids in the recovery of metals from scrap and metal oxides [11,12] as well as applications across a range of chemical processing [13], there has been only limited attention paid to the possibility of using ILs to recover metals from e-waste [14-16]. The present work is focused on investigation of a new approach for recovery of silver and gold from e-waste by sono-extraction in Ethaline (at $20 \mathrm{kHz}$ ). Ultrasonic leaching of precious metals ultrasound is a effective technique to extract metals such as precious metals. This process of ultrasonically assisted solid-liquid extraction is known as sono-leaching. The application of sono-leaching helps in dissolution of metals at a faster rate and higher recoveries are obtained in shorter duration. The use of ultrasonic stirring allows counteracting the negative effect of viscosity on the mass transport.

\section{Experimental part}

The background electrolyte was prepared by mixing the choline chloride $(\mathrm{ChCl}$, Aldrich $98 \%$, dried for 24-120 hours at $353 \mathrm{~K}$ ) with ethylene glycol (EG, Aldrich 99\%); by heating in a beaker the two components in 1:2 molar ratio at above $333 \mathrm{~K}$ for $30 \mathrm{~min}$, until a homogeneous and colorless liquid was formed. For the cyclic voltammetry measurements $\mathrm{AgCl}$ and $\mathrm{AuCl}$ (99.9\%, Sigma Aldrich) reagents were used as precursors of $\mathrm{Ag}^{+} \mathrm{and}^{\mathrm{Au}}$ ions, being dissolved easily in the supporting electrolyte ChCl-EG. The density value of ChCl-EG of $1.09 \mathrm{~g} \cdot \mathrm{cm}^{-3}$ determined in our laboratory at $343 \mathrm{~K}$ [17-19] was used in order to calculate the solution molarities.

In order to determine the mechanism of metals electrodeposition we used cyclic voltammetry (CV) technique. For the CV measurements the electrochemical cell was connected to a PARSTAT 2273 potentiostat driven by PC computer. A platinum sheet $\left(0.5 \mathrm{~cm}^{2}\right)$ was used as working electrode, whereas the auxiliary electrode was a platinum mesh. A silver wire immersed in the working electrolyte was the quasi-reference electrode [20]. The working electrode was polished mechanically with alumina oxide paste, washed with bi-distilled water and dried prior to measurement. Electrochemical experiments were performed via a $100 \mathrm{~mL}$ jacketed cooling glass cell linked to a thermostated bath. The voltammograms were recorded with different scan rates of $10-100 \mathrm{mV} \cdot \mathrm{s}^{-1}$. Supplementary voltammetric measurement was performed for determining the electrochemical window of the above solvent.

The multi-component e-waste sample (named S1) was obtained by melting in the microwave oven the cake resulting from PCB milling (dimensions $<5 \mathrm{~mm}$ ). After melting, it was poured as an ingot into a metallic chill cast, with dimensions of the ingot $(\mathrm{L} \times 1 \times \mathrm{h}) 200 \times 80 \times 30 \mathrm{~mm}$. Three succesively anodic dissolution processes were used in order to obtain the sample S1.

Recent studies have been carried out to investigate anodic dissolution, a new and very promising method for the recovery of metals from WPCBs [16,21]. This method consists of the direct extraction of metals through an electrochemical process without a prior chemical dissolution. The selective cathodic deposition of the studied $\mathrm{Ag}$ and $\mathrm{Au}$ from the sample $\mathrm{S} 1$ was carried out in a electrolysis cell $(150 \mathrm{~mL}$ capacity) with one copper cathode $(60 \times 30 \times 0.2$ $\mathrm{mm}$ ) and a central cast anode, immersed in the ChCl-EG electrolyte with $0.1 \mathrm{M}$ of pure iodine as oxidizing agent $[9,22]$. The selectivity of metal deposition is enhanced by the controlled potential electrolysis, based on the different reduction potentials for metals. The role of iodine oxidising agent is presented in results and discussion part of this paper.

In fact dissolving S1 and selective deposition of metals take place once. The temperature of the electrolyte was set at $303 \mathrm{~K}$ using a thermostat. The electrodeposition process was realized using a stabilized power supply-I 4115 IEMI Romania of $30 \mathrm{~V}-15$ A conected with a Hewlett Packard 34401A multimeter. During the experiments the cell voltage was between 0.1-1.0 V depending on which metal we want to deposit and the anodic current density was 0.01-0.2 $\mathrm{A} \cdot \mathrm{cm}^{-2}$. In order to speed up the dissolution process the electrolysis cell was introduced into an ultrasonic bath. After deposition the covered substrate was thoroughly washed with deionised water followed by acetone and ethanol to REV.CHIM.(Bucharest) $71 \bullet$ no. $1 \bullet 2020$ 
completely remove the residual ILs. The thickness of metal deposits is determined with the aid of compact inverted metallurgical microscope GX41 with the accuracy of $\pm 0.1 \mu \mathrm{m}$ on the polished end face of the substrate from copper thickness $\left(\mathrm{d}_{\mathrm{Cu}}=0.5 \mathrm{~mm}\right)$ and deposited coating layer.

For microstructure of the metal deposits obtained we used X-ray diffraction (XRD) and scanning electron microscopy (SEM). The crystal structure of gold and silver was characterized by XRD using X-ray diffractometer (model DRON-2, Russia) with $\mathrm{Cu}-\mathrm{K}_{\alpha}$-radiation $(\lambda=0.154 \mathrm{~nm})$ working at $2 \mathrm{~kW}$. X-ray patterns were obtained by the automatic recording of reflection intensities using a $0.03^{\circ}$ scanning step and 2-3 s exposition time per step. The obtained XRD data were analyzed with the Rietveld-type refinement FullProf program.

The morphology of the obtained thin films was analyzed by SEM using a Zeiss EVO-LF10 apparatus working at an accelerating voltage of $15 \mathrm{kV}$ and a FEI Quanta 3D FEG operating at 20-30 kV, equipped with an energy dispersive X-ray spectrometer (EDX). Surface analysis of the obtained thin films performed by X-ray photoelectron spectroscopy (XPS) was carried out on a Quantera SXM equipment, as presented in a previous paper [23]. The deconvoluted peaks were identified by reference to an XPS data base [24].

\section{Results and discussions}

Preparation and chemical analysis of e-waste sample

The three anodic dissolution processes (1,2 and 3) for obtaining the $\mathrm{S} 1$ sample from e-waste were carried out in an electrolyte containing $150 \mathrm{~g} \mathrm{~L}^{-1} \mathrm{H}_{2} \mathrm{SO}_{4}, 120 \mathrm{~g} \mathrm{~L}^{-1} \mathrm{CuSO}_{4} \times 5 \mathrm{H}_{2} \mathrm{O}$ and

$1 \mathrm{~g} \mathrm{~L}^{-1}$ bone glue, which was used as brightening agent for the improvement of the cathodic deposit. The dissolutions took place at an applied potential of 0.4-0.5 V. Two stainless steel foils $(80 \times 100 \times 0.5 \mathrm{~mm})$ were used as cathodes, placed symmetrically to the central anode (e-waste ingot or anodic slime ingot). After the first anodic dissolution process, the cathodic deposit contains $\mathrm{Cu}$ and $\mathrm{Cu}-\mathrm{Sn}$ alloy. The anodic slime obtained from the first dissolution was collected from the bottom off the cell, washed abundantly with distilled water and dried in an oven at $353 \mathrm{~K}$. The dried anodic slime was mixed with a melting flux $\left(80 \% \mathrm{Na}_{2} \mathrm{CO}_{3}\right.$ and $\left.20 \% \mathrm{Na}_{2} \mathrm{~B}_{4} \mathrm{O}_{7}\right)$, melted in an electric furnace and cast into a metallic ingot. The obtained ingot was subjected to a new anodic dissolution (anodic dissolution 2). After this second dissolution on cathode was obtained metallic $\mathrm{Cu}$ of $>99.5 \%$ purity. Afterwards, the process was repeated for the third dissolution (anodic dissolution 3). The chart of these three successive dissolutions is presented in Fig. 1.

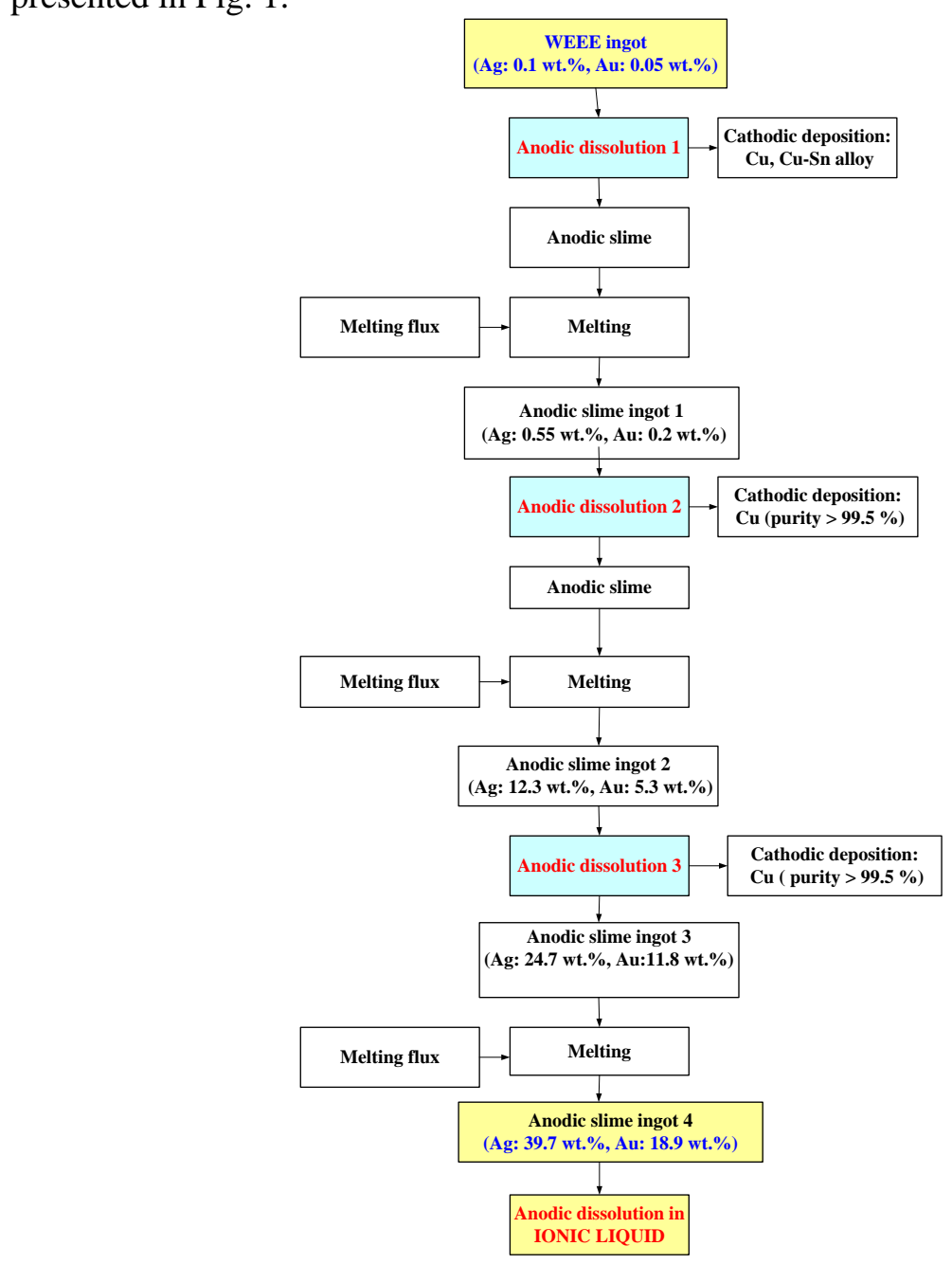

Fig. 1. The chart of the three anodic dissolutions used in order to obtain the $\mathrm{S} 1$ sample 
Three samples were taken from different areas of the final ingot, the samples were analyzed by: a) Inductively coupled plasma optical emission spectrophotometry ICP-OES for $\mathrm{Cu}, \mathrm{Sn}, \mathrm{Zn}, \mathrm{Pb}, \mathrm{Fe}, \mathrm{Ni}$; b) FAAS atomic absorption spectrometry for $\mathrm{Au}, \mathrm{Ag}$.

Chemical composition (wt.\%) of the processed e-waste sample (S1) was: Ag:39.7; Au:18.9; Sn:22.5; Cu:13.98; $\mathrm{Pb}: 3.5 ; \mathrm{Fe}: 0.12$; Ni:0.92; Sb:0.33; Cr:0.05.

\section{Investigation by cyclic voltammetry of dissolution/deposition proceses}

A series of $\mathrm{CV}$ experiments were performed for determining the dissolution/deposition potentials of the studied metals. Curve 1 in Figure 2 presents an example of the voltammogram in ChCl-EG (1:2 molar ratio) eutectic as supporting electrolyte. It was noticed the large domain of potentials (from $-1.5 \mathrm{~V}$ to $+0.4 \mathrm{~V}$ ) representing the potential window of $\sim 2 \mathrm{~V}$ for selected ILs, which is about $\sim 2$ times wider in comparison with similar parameter of aqueous solutions $(1.23 \mathrm{~V})$. In the condition in which we add iodine to ChCl-EG, curve 2 in Figure 2, on the voltammogram appears two peaks at $0.266 \mathrm{~V}$ and respectively at $0.672 \mathrm{~V}$, peaks which represent the reduction and oxidation of iodine and which we will prove later that do not interfere with silver or gold reduction.

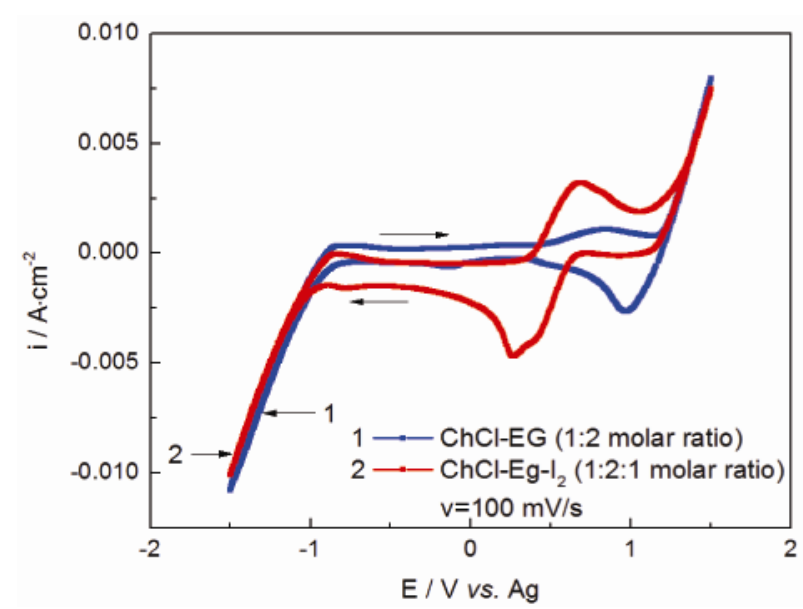

Fig. 2. Cyclic voltammogram on Pt within extended potential range for (1ChCl-2EG) eutectic and a $0.1 \mathrm{M} \mathrm{I}_{2}$ solution at $343 \mathrm{~K}$, scan rate $100 \mathrm{mV} \cdot \mathrm{s}^{-1}$

As can be seen, the voltammogram of $I_{2}$ solution in Ethaline shows two reversible redox couples, one of which being the $\mathrm{I}_{2} / \mathrm{I}^{-}$couple. The second redox couple suggests that another species is also formed in solution - possibly a trihalide species, such as $\mathrm{I}_{3}{ }^{-}$or $\mathrm{I}_{2} \mathrm{Cl}^{-}$. The position of the iodine redox couples at much more positive potentials with respect to the majority of the other metal deposition and oxidation couples reinforces the potential for iodine to be used as an oxidising agent in DES media $[11,12]$.

The reduction potential of iodine is quite high positive, compared to the oxidation potentials of different metals which should allow oxidative leaching of these elements.

Figure 3 shows the general relationships between the oxidation on set potentials in Ethaline $v s$. the $\mathrm{E}^{0}$ values for aqueous solutions. Whilst the absolute values are not comparable, it is apparent that in the ILs, the relative potentials and some times even the order in which the metals are oxidised are different from the aqueous solution. Through the centre of the graph is the line of equivalence, where electrode potentials would be identical in both solutions.

We can state that in the Ethaline, the location of iodine couple with respect to the other metal couples makes it an effective oxidising agent, which can be used for metal dissolution and recovery. The cathodic peak of iodine does not interfere with any of the reduction peaks of $\mathrm{Au}$ and $\mathrm{Ag}$.

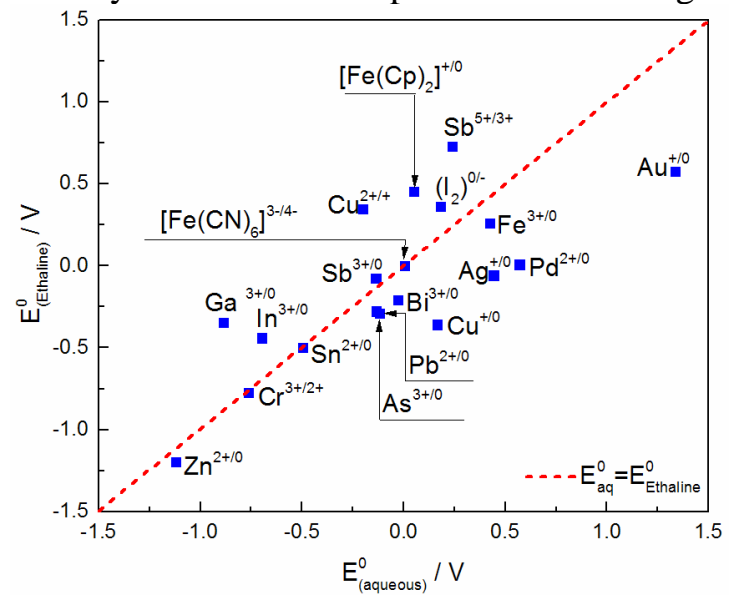

Fig. 3. Formal electrode potentials of a selection of metal species in Ethaline compared with potentials in aqueous solution, corrected for temperature and concentration [11]. 
However, in an industrial process the iodine has the potential to be employed as an electrocatalyst, whereby it is continuously recovered in situ from the reduced iodide by electrochemical oxidation at the anode of a cell (Fig. 4). Figure 4 shows the formal electrode potential $\left(\mathrm{E}^{\circ}\right)$ with respect to the line of equality, that is, when redox potentials are identical in both solvents, ILs and aqueous. For redox couples below this line, oxidation is easier in the ILs compared to aqueous solutions. In theory, the process should proceed as shown in the Figure 4 where the two metals are simultaneously oxidised, followed by selective electrowinning of one metal at the cathode and recycling of iodine at the anode. Dissolved metals can be selectively deposited at the cathode by adjusting the electrode potential $[9,11$, $12,25-26]$.

\section{Silver deposition}

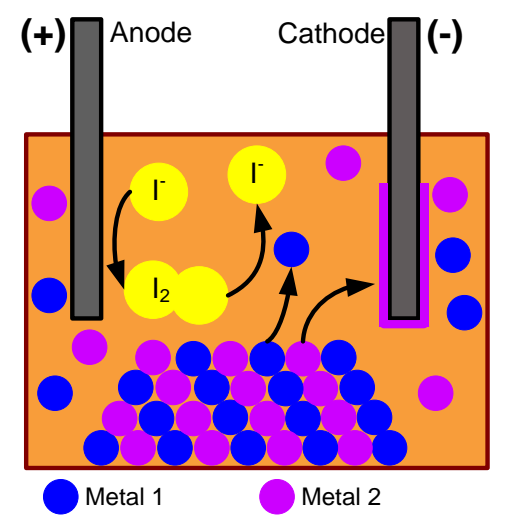

Fig. 4. Schematic diagram of the separation and recovery of two metals (Metal 1 and Metal 2) using iodine as an electrocatalytic oxidation agent [11].

Figure 5 shows the $\mathrm{CV}$ of silver electrodeposition from Ethaline recorded for a Pt working electrode with $50 \mathrm{mV} \cdot \mathrm{s}$ ${ }^{1}$ scan rate. Starting from the stationary potential ( $0 \mathrm{~V} v s$. Ag quasi reference electrode),CV curve shows clearly the beginning of cathodic deposition process with a current peak located at electrode potential $-0.073 \mathrm{~V}$, followed by a quite large potential region of limiting currents. By further polarizing of the Pt electrode (not shown here) a continuous increase of cathodic current at potentials more negative than $-1.2 \mathrm{~V}$ was recorded, suggesting a supplementary process of the ILs solvent together with the massive deposition of Ag on working electrode. In the voltammogram, by returning the electrode potential in the anodic direction a single well pronounced peak was obtained, with a peak potential located at $0.074 \mathrm{~V}$. Those two peaks represent the reduction and striping dissolution of silver onto the platinum electrode and the iodine does not interfere with none of them. The increase of current at potentials more positively than $+1.2 \mathrm{~V}$ (not shown, too) was attributed to the anodic process of supporting electrolyte, being probably the chlorine evolution. This result is in good agreement with literature data $[23,27]$. The oxidation potentials of silver is significantly more negative than the reduction potential of iodine, allowing electrocatalytic oxidation to proceed.

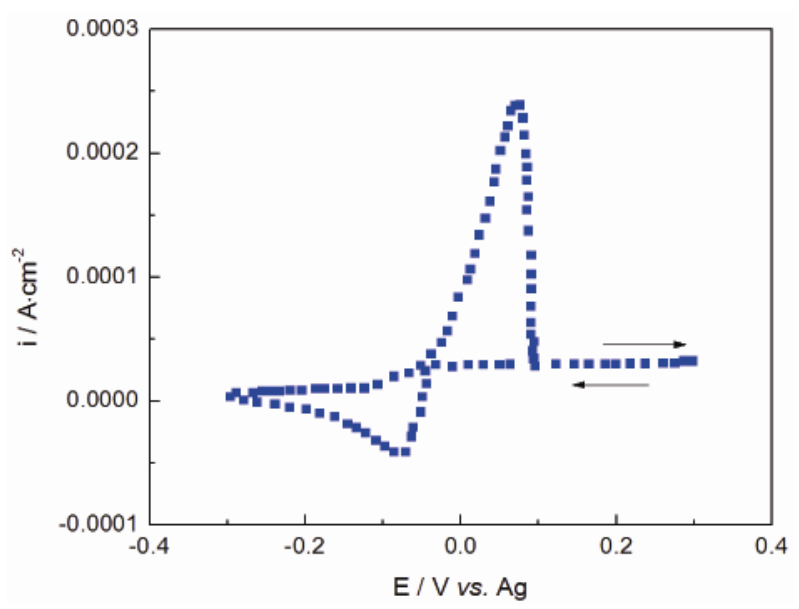

Fig. 5. Cyclic voltammogram for a Pt electrode $\left(0.5 \mathrm{~cm}^{2}\right)$ in $\mathrm{ChCl}-\mathrm{EG}$ containing $0.05 \mathrm{M} \mathrm{AgCl}, 343 \mathrm{~K}$; scan rate $50 \mathrm{mV} \cdot \mathrm{s}^{-1}$

The selective galvanostatic deposition tests for $\mathrm{Ag}$ from $\mathrm{S} 1$ sample in ChCl-EG-I $\mathrm{I}_{2}$ electrolyte at room temperature (298-303 K) led to light grey silver coatings, with a good adherence and uniformity. Usually, the experiments showed a difficulty to electrodeposit the silver layer, mainly due to the instantaneous nucleation process that determines the formation of a powdery deposit which further impedes a suitable adhesion. However, it should be mentioned that the ChCl-EG containing supplementary $\mathrm{I}_{2}$ (as catalytic/oxidizing agent) allowed the easily formation silver coatings on $\mathrm{Cu}$ support. The operation parameters were: 298-303 K working temperature, 30-60 min electrolysis time, 0.1 V voltage and $10 \mathrm{~mA} \cdot \mathrm{cm}^{-2}$ current density. 
Figure 6 presents an example of optical microscopy image of the obtained silver deposit, which shows that an ordered and uniform metallic coating has been formed that almost entirely covers the copper substrate.

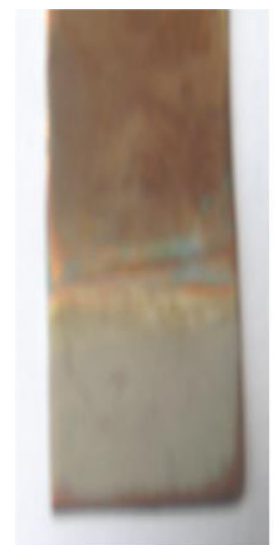

(a)

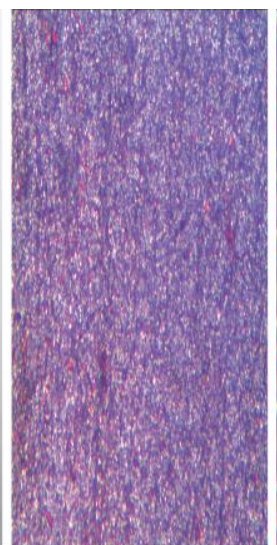

(b)

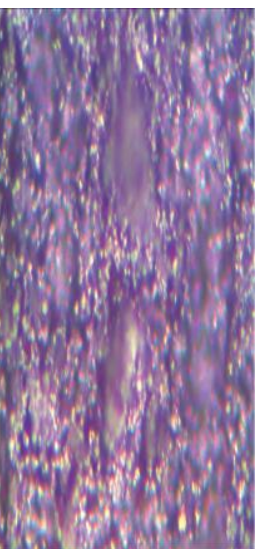

(c)
Fig. 6. Optical micrographs for Ag coatings deposited from ChCl-EG-I2 on copper substrate at $303 \mathrm{~K}$ for $30 \mathrm{~min}$ : photo image (a); and magnifications $\times 100(b) ; \times 800$ (c)

XRD measurements were carried out to get more information on composition and structure of the obtained silver deposit. According to the XRD patterns the deposit is formed of pure Ag. However, owing to its small thickness there are also evidenced the characteristic peaks at angles (20) corresponding to the $\mathrm{Cu}$ substrate, as it can be seen in Figure 7. The $\mathrm{Cu} \mathrm{K}_{\alpha}$ radiation X-ray of $\mathrm{Ag}$ thin layer on coper substrate in $20^{\circ} \leq 2 \theta \leq 100^{\circ}$ angle range contains reflexes of coper and of $\mathrm{Ag}$ (111), (200), (220), (311), (222) of cubic structure of Fmm (225) space group with the unit cell parameter $\mathrm{a} \approx 0.4099 \mathrm{~nm}$. This is in agreement with the data base [28]. The average size of crystallites was calculated using the Scherrer equation. The grain size was found to be equal to $\mathrm{d}_{\text {cryst }} \approx 28.04 \mathrm{~nm}$ and the dislocation density $\delta \cdot 10^{-}$ $3=1.27 \mathrm{~nm}^{-2}$.

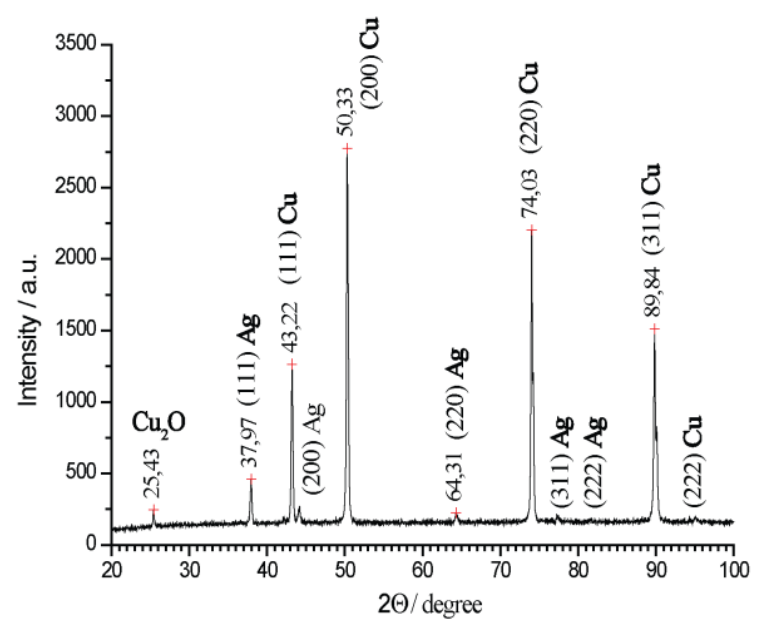

Fig. 7. XRD pattern for Ag deposit obtained from sample $\mathrm{S} 1$ in ChCl-EG-I2

The morphology of the deposited silver layer was characterized by SEM/EDX analysis. Figure 8 (a-d) showed that silver grows as large crystalites in the form of acicular leaves and EDX spectrum confirms that the deposit consisted of pure silver (Fig. 8-e).

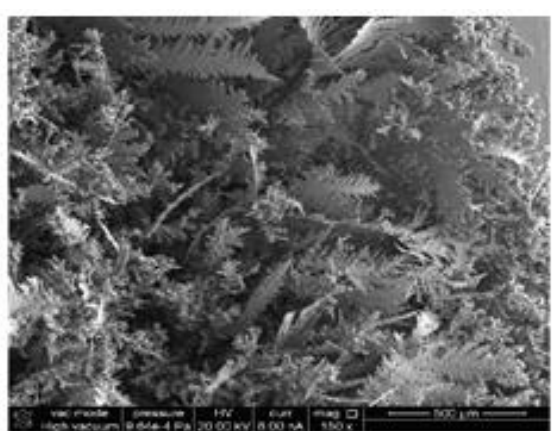

(a)

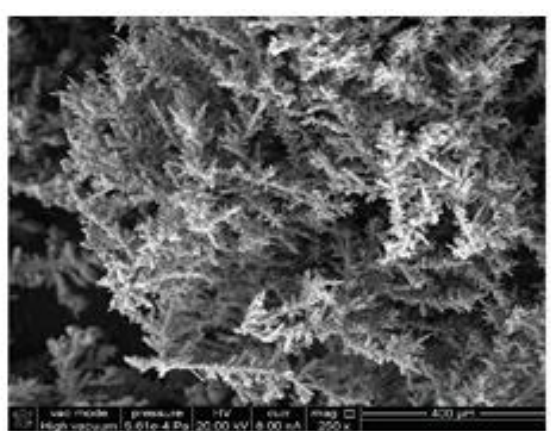

(b) 


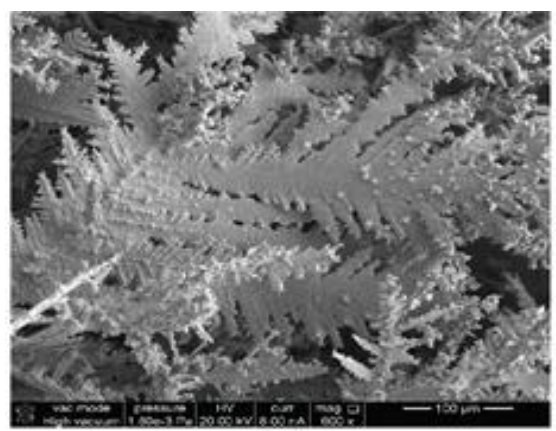

(c)

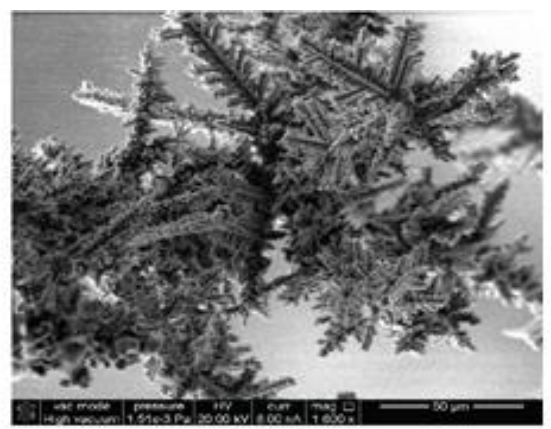

(d)

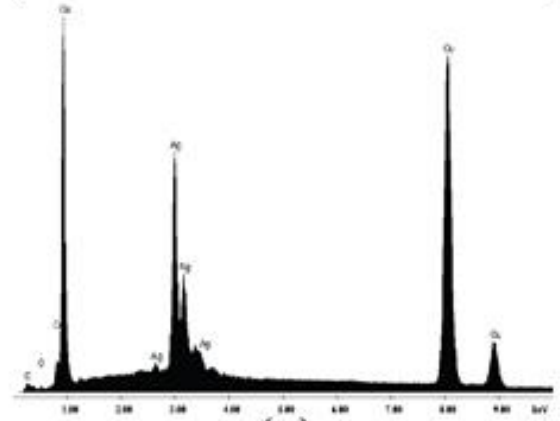

(e)

Fig. 8. SEM images of electrodeposited Ag from ChCl-EG-I 2 at magnifications: a) $\times 150$; b) $\times 250$; c) $\times 600$;

d) $\times 1600$; e) EDX spectrum

XPS analysis was used to determine the chemical states of the elements present on the surface of the obtained deposit on copper substrate. Survey (wide scan) XPS spectra were recorded to detect all the elements present on the surface $(<10 \mathrm{~nm})$. High resolution spectra were collected to find out the chemical bonding of the detected elements and for quantitative analysis, as well. Thus, the characteristic XPS spectra were recorded for the most prominent transitions for $\mathrm{C}, \mathrm{O}$ and $\mathrm{Ag}$ and no chloride $(\mathrm{Cl})$ was detected. A very weak O1s peak which might result from the adsorbed oxygen after the codeposition, was recorded. From the calculated results, substantial amounts of $\mathrm{C}$ were detected on surface, which may be attributed to the contamination of the surface with unavoidable carbon from $\mathrm{CO}_{2}$ adsorbed on the outermost layer from ambient atmosphere. To further determine the film components, high resolution XPS spectra of $\mathrm{C} 1 \mathrm{~s}, \mathrm{O} 1 \mathrm{~s}, \mathrm{Ag} 3 \mathrm{~d}$ were recorded. The spectra were then fitted using Gaussian-Lorentzian curves modified by a tail function, after back subtraction following the Shirley procedure[29-31]. Figure 9 presents the deconvoluted XPS spectrum for silver. Ag3d region has well separated spin-orbit components and peaks have asymmetric peak shape for metal. Binding energies of Ag characteristic energy were found to be $368 \mathrm{eV}$ for $\mathrm{Ag} 3 \mathrm{~d}_{5 / 2}$ and $375 \mathrm{eV}$ for $\mathrm{Ag} 3 \mathrm{~d}_{3 / 2}$.

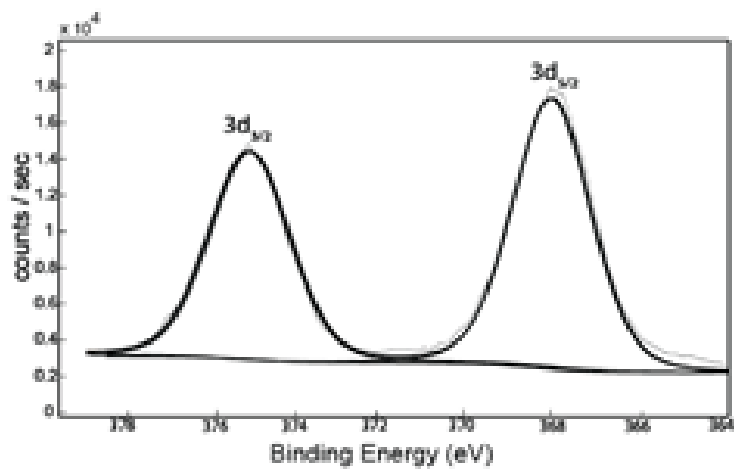

Fig. 9. The peak deconvolution of narrow area spectra of silver (Ag3d) for the deposited silver from $\mathrm{S} 1$ in the electrolyte ChCl-EG-I 2

\section{Gold deposition}

Figure 10 shows the voltammetric profile of gold electrodeposition on Pt electrode for the ChCl-EG electrolyte. When $\mathrm{Au}^{+}$ion is added to Ethaline a well-defined peak is observed at $0.468 \mathrm{~V}$ in the cathodic scan that can be attributed to the reduction of $\mathrm{Au}^{+}$ion. The reverse sweep shows only one anodic stripping peak at $0.696 \mathrm{~V}$ corresponding to the oxidizing of gold. Comparison to silver, the oxidation potential of gold is near the reduction potential of iodine $(0.674 \mathrm{~V})$. Closer introspection of cyclic voltammetry of iodine in Ethaline (curve 2 in Fig. 2) reveals that iodine undergoes two redox process: respectively the reduction of $\mathrm{I}_{2}$ and $\mathrm{I}_{3}{ }^{-}$as described above. The more 
anodic couple for iodine reduction has a slightly negative potential than $\mathrm{Au}^{\mathrm{I} / 0}$ couple, suggesting that a sufficiently higher concentration of iodine should enable the oxidation of gold [9].

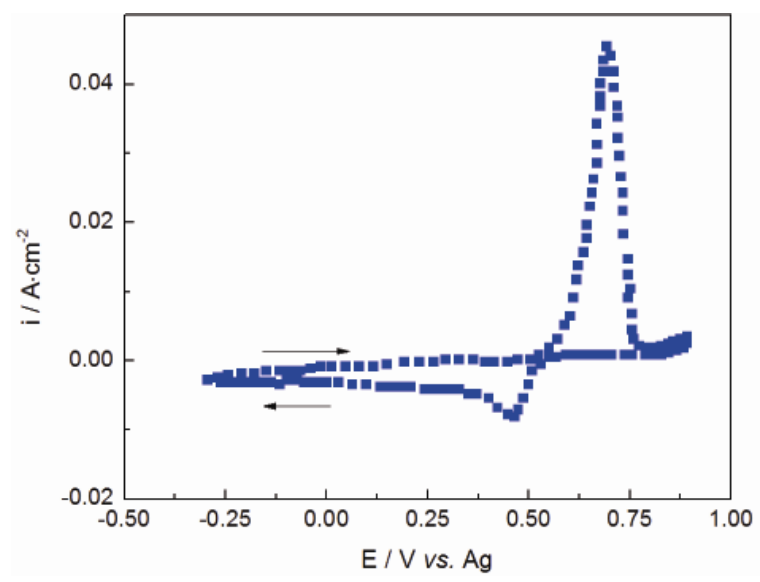

Fig. 10. Cyclic voltammogram for Pt electrode $\left(0.5 \mathrm{~cm}^{2}\right)$ in $\mathrm{ChCl}-\mathrm{EG}$ containing $0.05 \mathrm{M} \mathrm{AuCl} ; 343 \mathrm{~K}$, scan rate $100 \mathrm{mV} \cdot \mathrm{s}^{-1}$.

The selective galvanostatic deposition tests for Au deposited from S1 sample in the electrolyte ChCl-EG-I $\mathrm{I}_{2}$ led to powdery brown/black deposit, with a good adherence and bad uniformity. The operation parameters were: 298-303 K working temperature, 30-60 min. electrolysis time, $0.7 \mathrm{~V}$ voltage and $25 \mathrm{~mA} \cdot \mathrm{cm}^{-2}$ current density.

Figure 11 presents an example of optical microscopy image of the obtained gold deposit, showing that the metallic coating is very thin and not homogenous, so it did not cover all the copper substrate (Fig. 11-a). This is very well seen on the micrographic images in Fig. 11-b,c where the copper substrate is seen through the gold deposit.

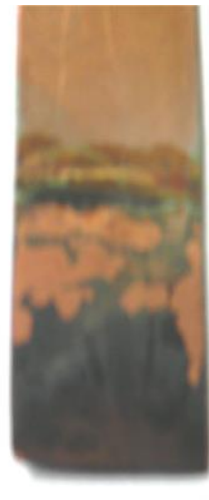

(a)

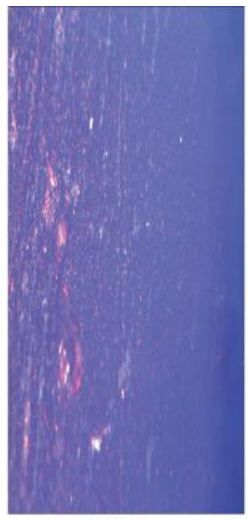

(b)

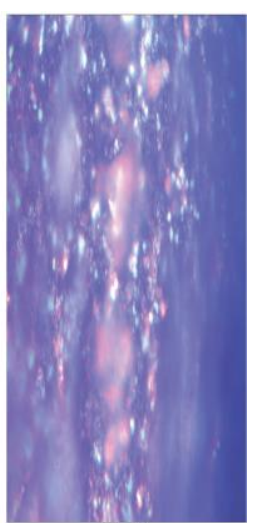

(c)
Fig. 11. Gold deposit from ChCl-EG-I2 on copper substrate: a) photo image;

micrographic images at magnifications: $b$ ) $\times 100 ; c) \times 800$.

Figure 12 shows an XRD pattern of the typical gold

nanoparticles. The characteristic peak for gold nanoparticles $\left(2 \theta=38.44^{\circ}, 44.74^{\circ}, 64.87\right.$ and $\left.77.76^{\circ}\right)$, marked by Miller indices: (111), (200), (220) and (311), showed that the resulting gold nanoparticles were essentially crystalline. The crystallite sizes can be estimated from the XRD data using Scherrer equation and were around $\mathrm{d}_{\text {cryst }} \approx 10.5 \mathrm{~nm}$.

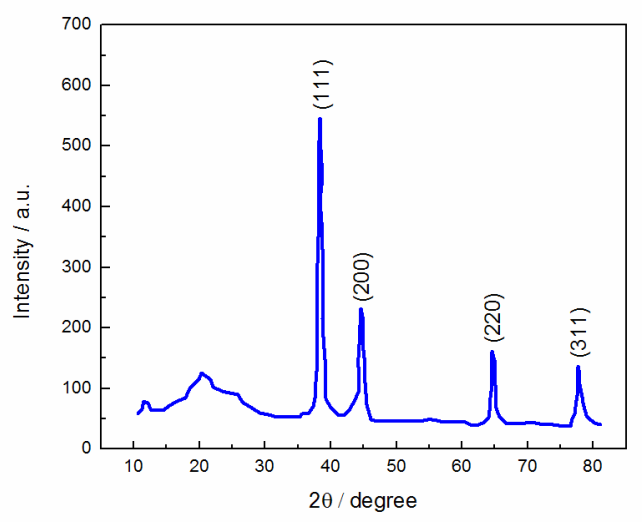

Fig. 12. XRD pattern for Au deposit from sample $\mathrm{S} 1$ in ChCl-EG-I2. 
The morphology of the deposited gold layer was characterized by SEM/EDX analysis presented in Figure 13(a-e). The SEM and EDX spectra demonstrate the deposition of an Au-containing phase on the $\mathrm{Cu}$ substrate. The micrographic images show that the deposit forms a continous coating layer, dense and clearly faceted, indicative of crystalline order. The facets of the Au-containing coating are several microns wide, therefore confering roughness to the coated substrate. A fine texture can be observed in higher resolution micrographs (Fig.13-c,d) with protruding features in the nanoscale or near nanoscale.

The EDX analysis (Fig.13-e) shows that the sample of copper substrate covered with the Au-containing phase has a mixture of $\mathrm{Au}, \mathrm{I}, \mathrm{Fe}$ and $\mathrm{Cr}$, but the concentrations vary at each point of analysis. For example, we determined the $\mathrm{Au}$ content from $30 \mathrm{wt} . \%$ to over $75 \mathrm{wt} . \%$. (from the analyzed area). The longer electrodeposition experiments resulted in very thick powdery black deposits. The shorter electrodeposition time resulted in the same morphology deposit which was considerably thinner.

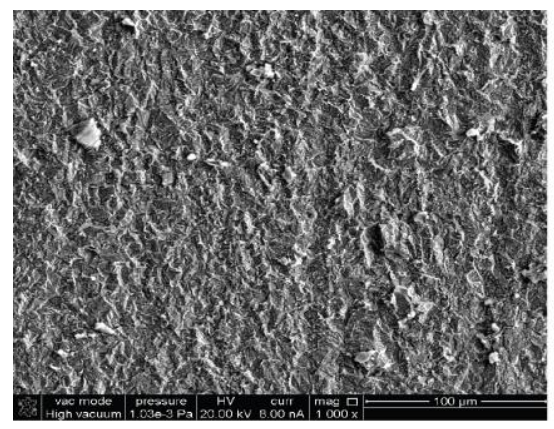

(a)

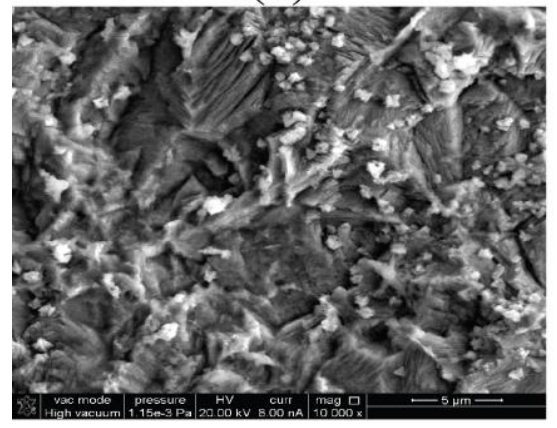

(c)

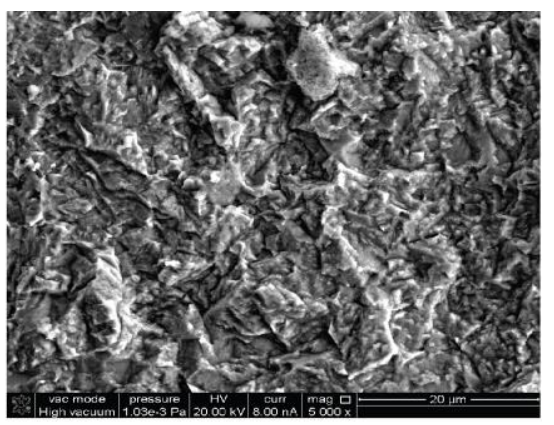

(b)

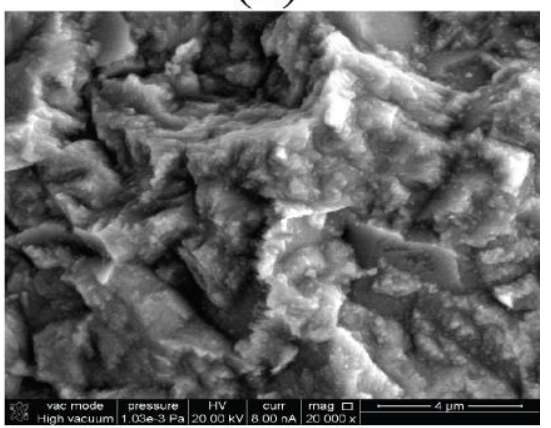

(d)

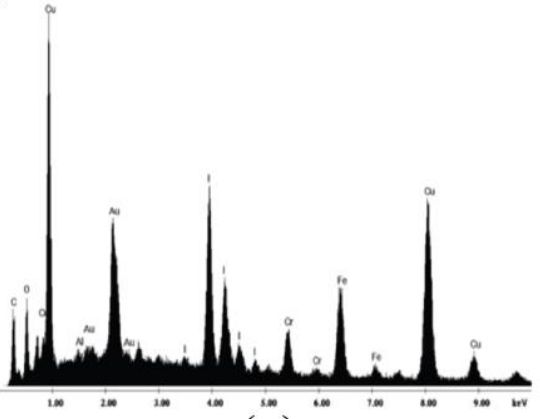

(e)

Fig. 13. SEM image of gold deposit at magnifications: a) $\times 1000$; b) $\times 5000$; c) $\times 10000$; d) $\times 20000$; e) EDX spectrum

XPS analysis detect the presence of $\mathrm{C}, \mathrm{O}, \mathrm{Au}, \mathrm{I}, \mathrm{Cr}, \mathrm{Fe}$ and $\mathrm{Cu}$. The deconvoluted spectrum for gold shows a single doublet $\mathrm{Au} 4 \mathrm{f}$ relating to $\mathrm{Au}(0)$ which characterizes our sample, the peaks in the Au4f region having an asymmetric peak shape (Fig. 14). The Au4f region has well separated spin-orbit components ( $\Delta=3.7 \mathrm{eV}$ ). Binding energies of $\mathrm{Ag}$ characteristic energy were found to be $87 \mathrm{eV}$ for $\mathrm{Au} 4 \mathrm{f}_{/ 2}$ and $84 \mathrm{eV}$ for $\mathrm{Au} 4 \mathrm{f}_{7 / 2}$. 


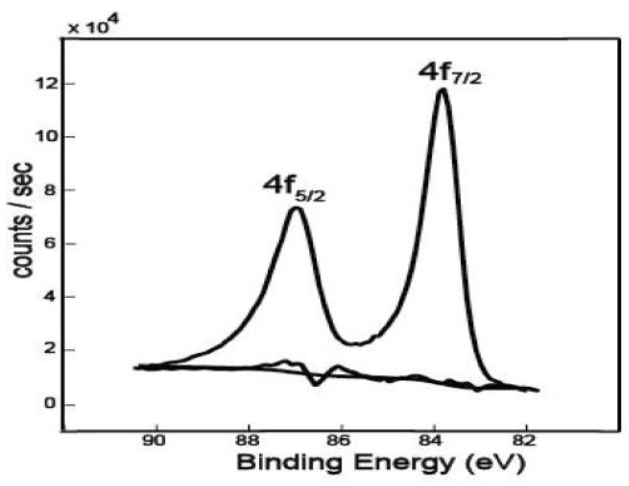

Fig. 14. The peak deconvolution of narrow area of XPS spectra of gold (Au4f) for the deposited gold from $\mathrm{S} 1$ in the electrolyte ChCl-EG-I2.

\section{Conclusions}

Silver and gold selective dissolving and deposition from e-waste by using choline chloride-ethylene glycol electrolyte and iodine as catalytic agent have been demonstrated.

The oxidation potentials of silver and gold were found to be significantly more negative than the reduction potential of iodine, allowing that the electrocatalytic oxidation to proceed. Electrodeposition resulted in a grey silver and black gold deposits, the thickness of which increased with deposition time and current density. The deposition potentials of silver and gold were sufficiently separated from each other therefore the individual elements could be recovered via electrowinning to a purity of $99 \%$ for silver and $30-70 \%$ for gold.

The selective extraction of silver and gold from a e-waste sample using an electrocatalytic method has also been demonstrated showing that this methodology could be appropriate to primary metal recovery.

Acknowledgements: This paper has been achieved with the financial support of MEN-UEFISCDI Romania, through Joint Applied Research Project PN-II-PT-PCCA-82/2014. Authors equally contributed to this work. We acknowledge to Royal Society of Chemistry for permission to reproduce/adapt figures from [11]

\section{References}

1. KAMBEROVIC, Z., KORAC, M., RANITOVIC, M., Metalurgija-MJoM, 17, 2011, p. 139.

2. LUDA, M.P., Recycling of Printed Circuit Boards, in Integrated Waste Management-Vol. II, KUMAR S.I., ed., InTech, , Rjeka, 2011, p. 285.

3. POPESCU, A.M., YANUSHKEVICH, K., SOARE, V., DONATH, C., NEACSU, E.I., CONSTANTIN, V., Chem. Res. Chinese Univ., 34, 2018 , p. 113.

4. JHA, M.K., LEE, J.C., KUMARI, A., CHOUBEY, P.K., KUMAR, V., JEONG, J., JOM, 63, 2011, p. 29.

5. FOGARASI, S., IMRE-LUCACI, F., IMRE-LUCACI, A., ILEA, P., J. Hazard. Mater., 273, 2014, p. 215.

6. VEIT, H.M., BERNARDES, A.M., FERREIRA, J.Z., TENORIO, J.A., MALFATTI, C.F., J. Hazard. Mater.,137, 2006 , p.1704.

7. *** European Commission; Directive 2002/96/EC on waste electrical and electronic equipment (WEEE). (21.01.2003) Official Journal of the European Union L, 37, 2003, p.24.

8. *** European Commission; Directive 2002/95/EC on the restriction of the use of certain hazardous substances in electrical and electronic equipment. (13.02.2003) Official Journal of the European Union L, 37, 2003, p.19.

9. ABBOTT, A.P., HARRIS, R.C., HOLYOAK, F., FRISCH, G., HARTLEY, J., JENKIN, G.R.T., Green Chem., 17, 2015 , p. 2172.

10. DALRYMPLE, I., WRIGHT, N., KELLNER, R., BAINS, N., GERAGHTY, K., GOOSEY, M., LIGHTFOOT, L., Circuit World, 33, 2007, p. 52.

11. ABbotT, A.P., FRISCH, G., GURMAN, S.J., HILlMAN, A.R., HARTLEY, J., HOLYOAK, F., RYDER, K.S., Chem. Commun., 47, 2011, p. 10031.

12. ABBOTT, A.P., FRISCH, G., HARTLEY, J., RYDER, K.S., Green Chem., 13, 2011, p. 471.

13. WASSERSCHEID, P., WELTON, T.,eds., Ionic Liquids in Synthesis, $2^{\text {nd }}$ ed, Wiley-VCH, Weinheim, 2008.

14. Ed. SABIR, S.,ed., The Recovery of Gold from Secondary Sources, Imperial College Press, London, 2016.

15. ROMAIN, F., Syntheses, characterisation and applications of ionic liquids to recover materials from WEEE. Dissertation, Brunel University, Institute for the Environment, London, 2010.

16. POPESCU, A.M., DONATH, C., NEACSU, E.I., SOARE, V., CONSTANTIN, V., Rev. Chim.(Bucharest), 67, no. 6, 2016 , p. 1076.

17. CONSTANTIN, V., ADYA, A.K., POPESCU, A.M., Fluid Phase Equilib., 395, 2015, p. 58.

18. POPESCU, A.M., DONATH, C., CONSTANTIN, V., Bulg. Chem. Commun., 46, 2014 p. 452.

19. POPESCU, A.M., CONSTANTIN, V., FLOREA, A., BARAN, A., Rev. Chim.(Bucharest), 62, 2011, p. 531.

20. GOLGOVICI, F., COJOCARU, A., ANICAI, L., VISAN, T., Mater. Chem. Phys., 126, 2011 p. 700.

21. SOARE, V., DUMITRESCU, D., BURADA, M., CONSTANTIN, I., SOARE, V., CAPOTA, P., POPESCU, A.M., CONSTANTIN, V., Rev. Chim.(Bucharest), 67, no. 5, 2016, p. 920.

22. ABBOTT, A.P., FRISCH, G., GARRETT, H., HARTLEY, J., Chem. Commun., 47, 2011, p. 11876.

23. NEACSU, E.I., CONSTANTIN, V., YANUSHKEVISH, K., GALYAS, A., DEMIDENKO, O., CALDERON-MORENO, J., POPESCU, A.M., Appl. Surf. Sci., 314, 2014, p. 30.

24. MOULDER, J.F., STICKLE, W.F., SOBOL, P.E., BOMBEN, K.D., Handbook of X-Ray Photoelectron Spectroscopy, CHASTAIN, J., KING JR, R.C.,eds., ULVAC-PHI Inc, Chigasaki, 1995.

25. ABBOTT, A.P., EL TTAIB, K., FRISCH, G., RYDER, K.S., WESTON, D., Phys. Chem. Chem. Phys., 14, 2012 , p. 2443.

26. JENKIN, G.R.T., AL-BASSAM, A.Z.M., HARRIS, R.C., ABBOTT, A.P., SMITH, D.J., HOLWELL, D.A., CHAPMAN, R.J., STANLEY, C.J., Mineral Eng., 87, 2016, p. 18.

27. FLOREA, A., PETICA, A., ANICAI, L., VISAN, T., UPB Sci. Bull. Series B, 72, 2010, p. 115. 
28. ICDD, PCPDFWIN v 2, JCPDS-International Center for Diffraction Data, diffraction pattern file card N.01-1167, 1998.

29. SHIRLEY, D.A., Phys. Rev. B, 5, 1972, p.4709.

30. ANICAI, L., SIN, I., BRINCOVEANU, O., COSTOVICI, S., COTARTA, A., COJOCARU, A., ENACHESCU, M.,VISAN, T., Appl. Surf. Sci., 175, 2019, p. 803.

31. SETHURAJAN, M., HULLEBUSCH, E.D. VAN, FONTANA, D., AKCIL, A.

DEVECI, H., BATINIC, B., LEAL, J.P., GASCHE, T.A., KUCUKER, M.A., KUCHTA K., NETO, I.F.F., SOARES, H.M.V.M., CHMIELARZ, A., Crit. Rev. Env. Sci. Tec., 49, 2019, p. 212.

Manuscript received: 6.12 .2019 